US Army Corps

of Engineers

Waterways Experiment

Station

Aquatic Plant Control Research Program

\title{
Propagation and Establishment of Aquatic Plants: A Handbook for Ecosystem Restoration Projects
}

by R. Michael Smart, Gary O. Dick

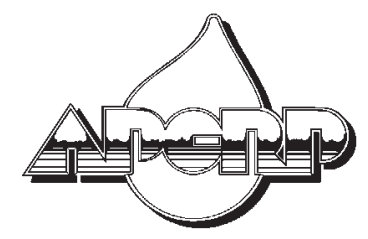

Prepared for Headquarters, U.S. Army Corps of Engineers 
The contents of this report are not to be used for advertising, publication, or promotional purposes. Citation of trade names does not constitute an official endorsement or approval of the use of such commercial products.

The findings of this report are not to be construed as an official Department of the Army position, unless so designated by other authorized documents. 


\section{Propagation and Establishment of Aquatic Plants: A Handbook for Ecosystem Restoration Projects}

by R. Michael Smart, Gary O. Dick

U.S. Army Corps of Engineers

Waterways Experiment Station

3909 Halls Ferry Road

Vicksburg, MS 39180-6199

Final report

Approved for public release; distribution is unlimited 


\section{Waterways Experiment Station Cataloging-in-Publication Data}

Smart, R. Michael.

Propagation and establishment of aquatic plants : a handbook for ecosystem restoration projects / by R. Michael Smart, Gary O. Dick ; prepared for U.S. Army Corps of Engineers.

37 p. : ill. ; $28 \mathrm{~cm}$. - (Technical report ; A-99-4)

Includes bibliographic references.

1. Aquatic plants - Handbooks, manuals, etc. 2. Benthic plants - Handbooks, manuals, etc. 3. Freshwater plants - Handbooks, manuals, etc. 4. Restoration ecology

-Handbooks, manuals, etc. I. Smart, R. Michael. II. Dick, Gary Owen, 1956- III. United States. Army. Corps of Engineers. IV. U.S. Army Engineer Waterways Experiment Station. V. Aquatic Plant Control Research Program (U.S. Army Engineer Waterways Experiment Station) VI. Title. VII. Series: Technical report (U.S. Army Engineer Waterways Experiment Station) ; A-99-4.

TA7 W34 no.A-99-4 


\section{Contents}

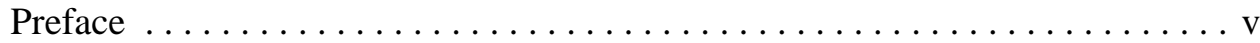

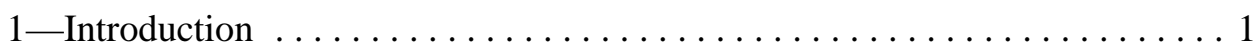

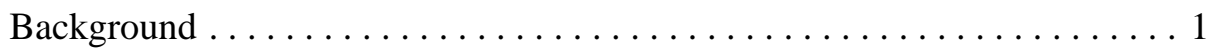

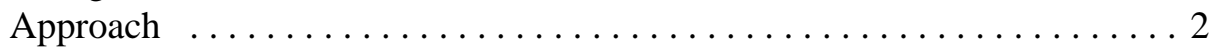

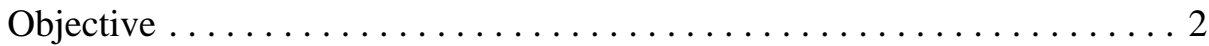

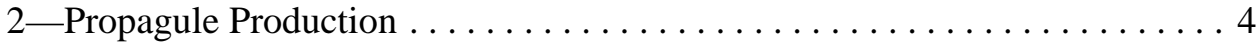

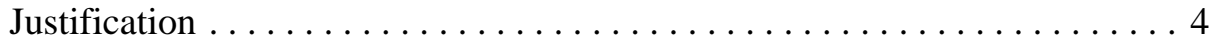

Plant Growth Requirements ..................... 5

Facilities for Offsite Production $\ldots \ldots \ldots \ldots \ldots \ldots \ldots \ldots \ldots \ldots$

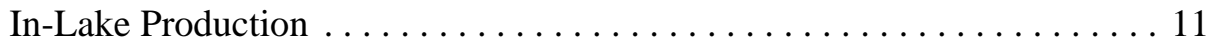

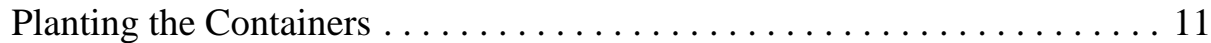

Propagule Types ............................. 13

Culture Maintenance . . . . . . . . . . . . . . . . . . . . . . . . . . . 14

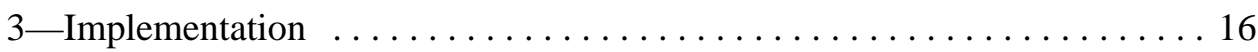

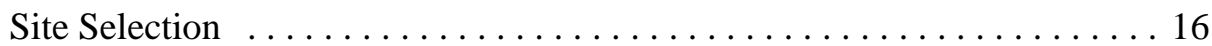

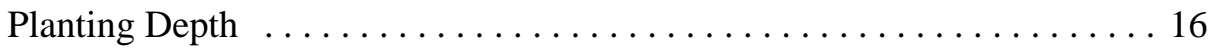

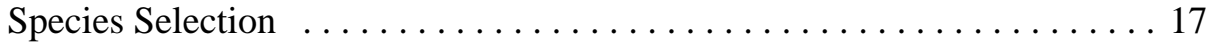

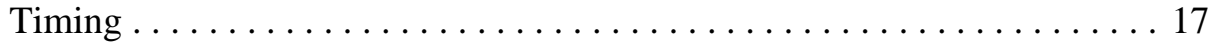

Herbivore Protection . ....................... 17

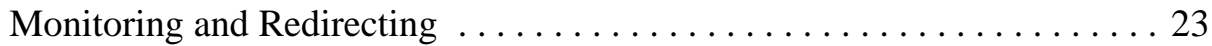

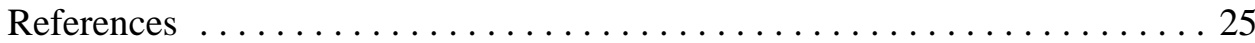

Appendix A: Production and Planting Information on Selected

North American Aquatic Plant Species . . . . . . . . . . . . . . A1

SF 298

\section{List of Figures}

Figure 1. Diagrammatic representations of founder colony approach . . . . 3

Figure 2. In-lake aquatic plant nursery $\ldots \ldots \ldots \ldots \ldots \ldots \ldots \ldots \ldots \ldots$ 
Figure 3. Individual plant protection cylinder $\ldots \ldots \ldots \ldots \ldots \ldots \ldots$

Figure 4. Multiple plant protection device $\ldots \ldots \ldots \ldots \ldots \ldots \ldots \ldots \ldots \ldots \ldots$

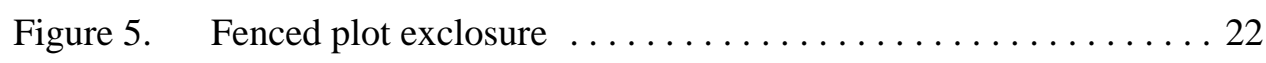

Figure 6. Diagram of fenced cove $\ldots \ldots \ldots \ldots \ldots \ldots \ldots \ldots \ldots \ldots$ 


\section{Preface}

The work reported herein was conducted as part of the Aquatic Plant Control Research Program (APCRP), Work Unit 33084 (Techniques for Establishing Native Aquatic Plants). The APCRP is sponsored by the Headquarters, U.S. Army Corps of Engineers (HQUSACE), and is assigned to the U.S. Army Engineer Waterways Experiment Station (WES) under the purview of the Environmental Laboratory (EL). Funding was provided under Department of the Army Appropriation Number 96X3122, Construction General. The APCRP is managed under the Center for Aquatic Plant Research and Technology (CAPRT) by Dr. John W. Barko, Director. Mr. Robert C. Gunkel, Jr., was Assistant Director for the CAPRT. Program Monitors during this investigation were Mr. Timothy Toplisek and Ms. Cheryl Smith, HQUSACE.

Principal Investigator for this study was Dr. R. Michael Smart, Ecosystem Processes and Effects Branch (EPEB), Environmental Processes and Effects Division (EPED), EL. The report was prepared by Drs. Smart and Gary O. Dick assigned to EPED under an Interpersonal Act Agreement with the Institute of Applied Science, University of North Texas, Denton, TX. The report was reviewed by Ms. Linda Nelson, EPEB, and Mr. David Honnell, AScI.

This investigation was performed under the general supervision of Dr. John Harrison, Director, EL; Dr. Richard E. Price, Chief, EPED; and Dr. Robert Kennedy, Acting Chief, EPEB.

At the time of publication of this report, Commander of WES was COL Robin R. Cababa, EN.

This report should be cited as follows:

Smart, R. M., and Dick, G. O. (1999). "Propagation and establishment of aquatic plants: A handbook for ecosystem restoration projects," Technical Report A-99-4, U.S. Army Engineer Waterways Experiment Station, Vicksburg, MS.

The contents of this report are not to be used for advertising, publication, or promotional purposes. Citation of trade names does not constitute an official endorsement or approval of the use of such commercial products. 


\section{Introduction}

\section{Background}

Aquatic ecosystem restoration often involves the establishment or reestablishment of aquatic plant communities. Most reservoirs without aquatic plants suffer from poor water quality (high nutrients, poor visibility, etc.), weak fisheries (absence of cover and nursery habitats), and are susceptible to invasions by weedy exotic plant species. The role of plants in aquatic systems is significant. Aquatic plants provide valuable fish and wildlife habitat (Dibble, Killgore, and Harrel 1996), serve as a food source for waterfowl and aquatic mammals, improve water clarity and quality (James and Barko 1990), reduce rates of shoreline erosion and sediment resuspension (James and Barko 1995), and help prevent spread of nuisance exotic plants (Smart, Barko, and McFarland 1994).

Three situations occur in large, multipurpose reservoirs that require restoration through establishment of native aquatic plants: an absence of vegetation, low species diversity, or infestation by nuisance exotic plant species such as hydrilla (Hydrilla verticillata). In the first two situations, restoration involves addition of desired species of aquatic plants, while in the latter, control of the invasive exotic species must be additionally addressed.

Aquatic plant communities in natural lakes develop over periods of hundreds or thousands of years. The average age of 672 Corps of Engineers' reservoirs is 40 years, and over half of these reservoirs are younger than 37 years. In these man-made systems, there has not been enough time for native aquatic plants to arrive and become established. Time is not the only limitation. The absence of propagule sources, harsh abiotic conditions, and biotic pressures all contribute to reducing the likelihood that aquatic plants will become established in a particular reservoir.

Reservoirs are often constructed in areas that lack natural lakes and may be remote from populations of aquatic plants that could serve as sources of propagules. As a result, many reservoirs have no aquatic plant seed bank and receive only limited inputs of seed and other plant propagules. These reservoirs are often first colonized by nuisance exotic weeds, which are adapted for exploiting disturbed conditions (Smart and Doyle 1995). Once established, 
nuisance exotic weeds can prevent establishment of native plants, regardless of subsequent propagule availability.

Unfavorable abiotic conditions include excessive water-level fluctuations, high turbidities, and shifting sediments. Small, young plants are especially vulnerable to changing water levels that may place them in water too deep or muddy to allow for adequate light penetration or so shallow as to expose them to turbulence or desiccation or cover them with sediments.

Biotic disturbances are caused by a number of aquatic and semiaquatic organisms. Fish and other animals that feed or "root" in sediments easily dislodge seedlings and other small, young plants. Also, herbivory by turtles, crayfish, insect larvae, muskrat, nutria, and beaver has been shown to be a significant factor affecting establishment and growth of submersed aquatic plant communities (Lodge 1991; Dick, Smart, and Keiser 1995; Doyle and Smart 1993, 1995; Doyle et al. 1997). These animals are all highly mobile, and many are widely distributed throughout river systems. Also, many of them are omnivorous, so their presence is not entirely dependent on the prior availability of plants. As a result of their mobility and widespread distribution, omnivores are generally present in sufficient numbers to prevent, or at least delay, natural establishment of aquatic vegetation. In some systems, grass carp have been used to control aquatic weed infestations, and their continued presence may prevent establishment of any aquatic plant species for many years (Smart, Dick, and Doyle 1998).

\section{Approach}

To overcome these impediments to natural establishment, an approach has been developed for establishing "founder colonies." Founder colonies are small colonies of aquatic plants established in strategic locations within the reservoir. Phase 1 involves planting of test plants within small protective exclosures. During the second growing season (Phase 2), additional protected transplants of the more successful species should be added. Depending on the level of herbivory noted during Phase 1, a larger fenced area may be required to allow the plants to expand beyond their protective cages. In the diagram (Figure 1), a cove is fenced and additional transplants are added. During the third and subsequent growing seasons (Phase 3), the founder colonies vegetate the rest of the reservoir. Once successfully established, these colonies expand through vegetative and sexual reproduction into adjacent, unvegetated areas (Figure 1). These founder colonies then serve as propagule sources for natural colonization throughout the lake (Smart et al. 1996; Smart, Dick, and Doyle 1998).

\section{Objective}

Successful establishment of founder colonies relies on planting of robust propagules (such as mature transplants) into protected sites (Smart et al. 1996; 


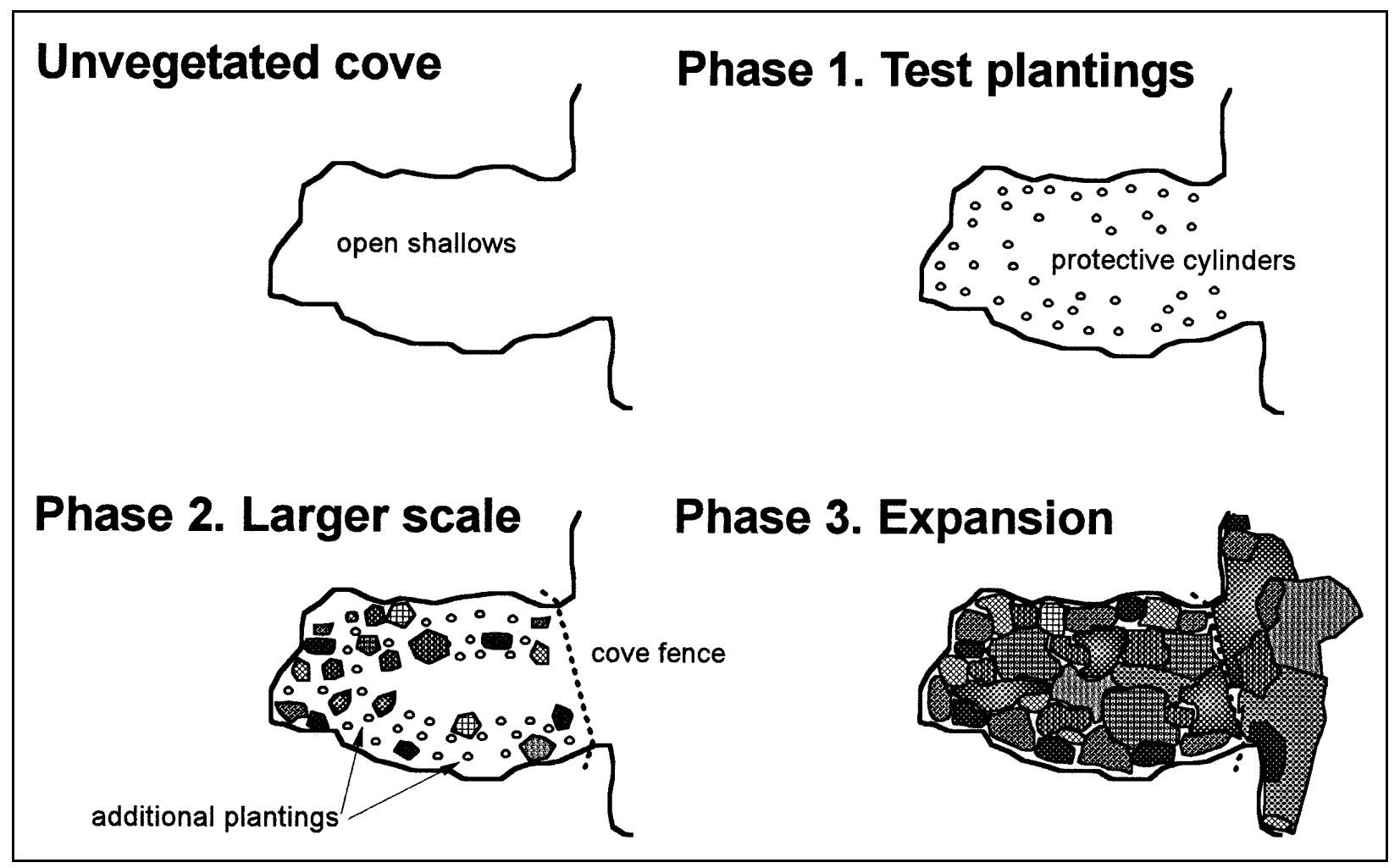

Figure 1. Diagrammatic representation of founder colony approach

Smart, Dick, and Doyle 1998). This handbook describes techniques for producing aquatic plant propagules and for planting these propagules in reservoirs.

This is a new technology, and the state of the art is increasing at a relatively rapid rate. Many of the techniques presented here have not yet been rigorously tested in multiple systems. While these methods have been used with some success, they may not be universally applicable-there are large differences among plant species, among different regions of the country, and even among reservoirs. Annual variations in weather and hydrology are also likely to affect the outcome of any plant establishment efforts. The techniques presented here are certainly not the only methods that can be used for establishing aquatic vegetation; many new techniques are being developed and evaluated at a number of reservoirs in several southern states. Likewise, the attempt thus far has been to establish only a few species on a large scale or in multiple situations. Establish-ment of additional species is being evaluated. Some of these new techniques and new species will prove successful while others may not. Because the technology is in its infancy and is developing at a relatively rapid pace, this handbook is intended to be a preliminary technology transfer product. The intention is to provide several extensive updates and revisions over the next few years as better information becomes available. 


\section{Propagule Production}

\section{Justification}

Each restoration project will require many individuals of several aquatic plant species. Even on the scale of founder colony establishment, the number of plants required can be quite high. Because acquisition of large numbers of appropriate propagules in a timely manner can be difficult, these authors have begun developing methods for producing transplants and other propagules, tailored for each specific project.

Although commercial suppliers may, in some cases, be used to provide some of the plant materials needed for the restoration project, propagule production may be preferred for several reasons. Currently, only a limited selection of aquatic plant species (particularly submersed plant species) is readily available from commercial sources. Propagule types offered are also frequently unsuited to the demands of plant establishment in large water bodies. For the most part, stem fragments, seeds, root crowns, or dormant perennating organs (tubers, winterbuds) are sold commercially. These propagules are weak and require near-ideal conditions for successful establishment. In the harsh environment of artificial reservoirs, most are destined to fail.

Additionally, such propagules are often only available at certain times of the year, very possibly at the wrong time of the year for a particular restoration project. One reason for this is geographic location of the commercial suppliers/collectors. As an example, northern suppliers generally must wait until spring thaws occur, which may be beyond the period for optimal establishment in southern reservoirs. In other cases, propagules may be readily available in the spring, but hydrologic conditions (e.g., spring flooding) may dictate planting at a later date. Plant material, even dormant propagules, may not survive holding for extended periods.

Plant origin may be an issue as well. Although the same species may be found throughout the United States, there may be considerable genetic variability among plants from different regions. These variations are likely due to differences in environmental (climatic or geological) conditions. A northern 
variety may not do well in southern climates. Finding source plants locally (or as locally as possible) is highly recommended.

This chapter is intended to be a guide for those who choose to produce their own propagules for lake restoration. Finding local plant stocks and cultivating desired species (and propagule types) may be the preferred technique for such projects. General requirements and considerations for the culture of a variety of aquatic plants are covered, including submersed, floating-leaved, and emergent growth forms. Specific information on several common North American species is given in Appendix A.

\section{Plant Growth Requirements}

\section{Considerations}

The key to growing any plant is to provide conditions that allow the plant to fulfill its need for nutrients and sustain a rate of photosynthesis sufficient to provide for respiration and growth. All plants (particularly aquatic plants) have a basic need for water and an environment that provides appropriate temperatures. Beyond these basic requirements, photosynthesis depends on adequate levels of light and a continual supply of inorganic carbon (dissolved carbon dioxide or bicarbonate), while nutrient uptake depends on a supply of critical nutrients. Table 1 indicates sites of nutrient uptake and photosynthesis for terrestrial and aquatic plants of different growth forms. These facts must be considered in the development of plant culture methods and facilities.

\begin{tabular}{|c|c|c|c|c|}
\hline \multicolumn{5}{|c|}{$\begin{array}{l}\text { Table } 1 \\
\text { Predominant Sites of Nutrient Uptake and Photosynthesis in Terrestrial and Aquatic } \\
\text { Plants of Different Growth Forms and Implications for the Culture of Aquatic Plants }\end{array}$} \\
\hline $\begin{array}{l}\text { Growth Form } \\
\text { (Example) }\end{array}$ & $\begin{array}{l}\text { Photosynthetic } \\
\text { Medium }\end{array}$ & Provide Inorganic Carbon by & $\begin{array}{l}\text { Predominant Site } \\
\text { of Nutrient Uptake }\end{array}$ & Add Nutrients to \\
\hline Terrestrial plants & Air & 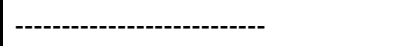 & Soil & Soil \\
\hline $\begin{array}{l}\text { Rooted, submersed } \\
\text { (Vallisneria americana) }\end{array}$ & Water & $\begin{array}{l}\text { Aeration, mixing, water } \\
\text { exchange, bicarbonate addition }\end{array}$ & Sediment & $\begin{array}{l}\text { Sediment, very } \\
\text { sparingly to water }\end{array}$ \\
\hline $\begin{array}{l}\text { Nonrooted, submersed } \\
\text { (Ceratophyllum demersum) }\end{array}$ & Water & $\begin{array}{l}\text { Aeration, mixing, water } \\
\text { exchange, bicarbonate addition }\end{array}$ & Water & Water \\
\hline $\begin{array}{l}\text { Floating-leaved } \\
\text { (Nymphaea odorata) }\end{array}$ & Air & Ensure adequate ventilation & Sediment & $\begin{array}{l}\text { Sediment, } \\
\text { sparingly to water }\end{array}$ \\
\hline $\begin{array}{l}\text { Emergent } \\
\text { (Scirpus validus) }\end{array}$ & Air & Ensure adequate ventilation & Sediment & $\begin{array}{l}\text { Sediment and/or } \\
\text { water }\end{array}$ \\
\hline $\begin{array}{l}\text { Free-floating } \\
\text { (Limnobium spongia) }\end{array}$ & Air & Ensure adequate ventilation & Water & Water \\
\hline
\end{tabular}


Unlike terrestrial plants, submersed aquatic plants conduct photosynthesis in a water environment (medium). This is important for several reasons.

a. The medium (in this case water) must be of sufficient clarity to transmit adequate light to the leaves. This is not usually a problem in air.

$b$. If the water contains nutrients, particularly phosphorus, excessive growth of algae can cause problems by reducing light penetration to the submersed macrophytes.

c. The medium must provide a continual supply of inorganic carbon. Again, this is not usually a problem in open-air environments; but the diffusion of carbon dioxide in water is slower than in air, and the concentration of carbon dioxide can be greatly reduced in water, particularly at $\mathrm{pH}$ levels greater than 8.3.

d. Algae will compete with submersed macrophytes for inorganic carbon.

Successful culture of rooted submersed aquatic plants will thus depend on the ability to provide adequate nutrients via the sediment to the plant roots and adequate levels of light and inorganic carbon via the water to the plant shoots (Smart and Barko 1985). Because nonrooted submersed aquatic plants must obtain all of these resources (nutrients, light, and carbon) via the water (Table 1), they are quite difficult to grow under artificial conditions due to competition with algae. For this reason, these authors do not at this time recommend culture of Ceratophyllum demersum and prefer to collect plants of this species from existing natural populations.

\section{Sediment substrate}

Submersed aquatic plants will grow in a variety of substrate types, ranging from pure sand to heavy clays. However, for optimum production a finetextured substrate with a low to moderate organic content (10 to 20 percent) is ideal for most species of submersed aquatic plants. Sandy substrates are unsuitable because they are generally infertile and added nutrients may diffuse into the water column, causing algal problems. Highly organic substrates can be inhibitory to plant growth (Barko and Smart 1983, 1986). When available, using fine-textured sediments from ponds or lakes in which aquatic plants are known to grow is recommended.

If the growth potential of sediments is in doubt, small-scale trails should be conducted to determine sediment suitability for supporting aquatic plant growth. Because suitable natural sediments may not always be available, the use of commercial potting soils or top soils may be necessary. For relatively smallscale efforts, bagged soils may be practical. In selecting a soil for aquatic use, generally the lowest priced product will be the most suitable, as it will generally contain the fewest additives. Avoid the use of products that contain bulk 
additives such as peat, vermiculite, perlite, or sand. For large-scale projects, local top soils may be purchased in bulk after ensuring their suitability.

\section{Fertilization}

Submersed aquatic plants. For short-term ( 2 months or less) cultivation of submersed aquatic plants, an initial fertilization of the potting medium is usually sufficient. Often, addition of nitrogen is required to achieve optimum growth (Smart et al. 1995). Rates of $1 \mathrm{~g}$ nitrogen per liter of medium are sufficient to support growth during this period. Nitrogen should be added as an ammonium salt, not as nitrate or urea. Nitrate can be rapidly lost from anaerobic sediments by diffusion and denitrification. Ammonium ions, however, are readily adsorbed and held on the cation exchange surfaces of clay minerals and macroorganics.

Longer term cultivation of submersed aquatic plants may require periodic fertilization or addition of other nutrients. Adding nitrogen as either ammonium or nitrate to the water column every few weeks can be used to sustain the growth of mature transplants. Excess levels of nitrogen can be inhibitory to the growth of submersed aquatic plants, so concentrations should not exceed 1 or $2 \mathrm{mg} / \mathrm{L}$.

Floating-leaved and emergent aquatic plants. Floating-leaved and emergent growth forms generally produce more biomass than do submersed forms and have proportionately greater demands for nutrients. For this reason, larger quantities of fertilizer should be added to the sediment substrate. Because these forms have their photosynthetic and carbon uptake surfaces in the air rather than the water, excessive algal growth generally does not interfere with their growth. In fact, once they develop a canopy of leaves, these plants may shade out algae. Long-term growth of cultures of these growth forms can be sustained by adding nutrients directly to the water without concern. Although these growth forms generally are not well adapted to absorb nutrients from the water, transpiration drives a movement of water (and dissolved nutrients) into the root mass. For this reason, using pots with ample "drain" holes is preferred so that the roots will be in close association with the water.

Free-floating-leaved aquatic plants. Free-floating aquatic plants, having their photosynthetic and carbon uptake surfaces in the air and their nutrient uptake surfaces (roots) in the water, are relatively easy to grow. A soluble, complete nutrient fertilizer can simply be added to the water as needed. While easy to grow, the use of free-floating aquatic plants for lake restoration is not recommended, as these can grow to excess under eutrophic conditions. Excessive growth of free-floating plants can completely cover the water surface and cause problems by interfering with the entry of sunlight and atmospheric oxygen. 


\section{Water quality requirements}

While floating-leaved and emergent plants are not as particular, a reliable source of high-quality water is required for growing submersed aquatic plants. Ideally, water should be clear and relatively nutrient free (at least phosphorus free). Clear water allows adequate light penetration. Under low light conditions, some plants will become leggy and produce weak root systems. Nutrient-rich water often leads to algal blooms in the culture, and these interfere with plant production by competing for light and inorganic carbon. The use of municipally treated water is not recommended, unless chlorine is first removed. Treated water also often contains relatively high levels of phosphorus.

For tank cultures, these authors use lake water that has been "polished" or treated to acceptable quality. In one method, a vegetated pond is used to reduce turbidity and remove much of the dissolved phosphorus from the water column. The water is simply pumped from a vegetated pond directly to the culture facilities. In a second method, the water is treated with aluminum sulfate (approximately $0.1 \mathrm{~kg}$ per $1,000 \mathrm{~L}$ ) to flocculate clays and suspended material and to remove phosphorus by sorption onto precipitates. The resultant floc is allowed to settle, and the clear water above can be pumped to culture tanks; if the water is treated in place, the floc can be pumped out and discarded. For a large-scale plant production system, a 1.5-m-deep, lined water supply pond is used as a reservoir. Lake water is pumped into the pond, treated with aluminum sulfate, and mechanically filtered with sand filters (Dick, Getsinger, and Smart 1997). The liner (generally polyvinyl chloride (PVC) or rubber) prevents nutrients and clay minerals from being released or suspended from the soil into the water column. This system provides an abundance of high-quality water.

Additional requirements for water that will be used to grow submersed aquatic plants include a source of inorganic carbon and a balanced chemical composition including calcium, magnesium, and potassium ions (Smart and Barko 1984, 1985). Periodic replacement of part of the water may be desirable to maintain favorable levels of alkalinity, dissolved inorganic carbon, and dissolved ions. Alternatively, additions of sodium or potassium bicarbonate and calcium (as either a sulfate or chloride salt) can be used to maintain adequate levels of these constituents. Aeration (see below) is also needed to maintain a steady supply of inorganic carbon.

\section{Water circulation and mixing}

In unlined, earthen ponds, sediment respiration provides an abundant and continuous supply of carbon dioxide to support the photosynthesis of submersed aquatic plants. However, in lined ponds or tanks, carbon dioxide availability may often be a factor limiting growth of submersed aquatic plants. (Floatingleaved and emergent species acquire carbon dioxide directly from the air). Conse-quently, aeration of tank cultures is recommended for submersed species. A regenerative blower/compressor aeration system is required to supply the air, 
and vigorous bubbling of atmospheric air through air stones usually provides adequate mixing in addition to supplying carbon dioxide.

\section{Facilities for Offsite Production}

Production of aquatic plant propagules requires adequate facilities, but these need not be complicated or expensive. Small ponds, tanks, or raceways may be used to grow aquatic plants. To minimize transportation costs, and the inevitable damage that occurs during transport of plant materials, production facilities should be as close as possible to the restoration site. In this regard, in-lake production, if possible, might be the most economical means of propagule production. In the following section, guidelines are provided on the suitability of various facilities for plant production.

\section{Containers}

Using commercial nursery pots with drain holes in the bottoms is recommended. As previously mentioned, these holes allow movement of dissolved nutrients into the sediment substrate where they can be taken up by the roots. Various sizes and shapes of commercial nursery pots are available. Both quart- (4-in. or 10-cm diameter) and gallon- (6-in. or 15-cm diameter) sized pots have been used for growing a wide variety of aquatic plant species. Commercial-grade nursery pots can be reused several times.

\section{Small ponds}

Well-designed ponds offer excellent sites for culturing aquatic plants. Although any pond that has a reliable water source (and water depth) will suffice, those in which drainage and filling are easily accomplished serve best. This allows the plant grower to manipulate water levels for cultivation needs such as planting, weeding, fertilizing, and harvesting. Because the objective is to produce robust, potted transplants, one wants to (as much as possible) restrict growth to the containers. Open-pond bottom sediments allow growth of endemic vegetation and encourage the "escape" of cultivated plants. Either of these situations is undesirable because plants growing "wild" in the pond reduce the growth of potted plants by competition and interfere with maintenance and harvesting operations. For these reasons, lined ponds are preferred over earthen ponds. However, construction of concrete pads on earthen pond bottoms also offers the same advantage.

Separation of plant species within a lined pond can be critical for successful cultivation of many species. Cross-contamination by faster (or earlier) growing species can reduce production of slower (or later) growing plants. Because many aquatic plants spread vegetatively from fragments, care must be taken when selecting species for polyculture within a single pond. Isolating fragmentspreaders (or prolific seed producers) in their own pond is highly recommended. 
A second option is to construct enclosures for these species. A fine-mesh shadecloth fencing will serve to prevent spread by fragmentation of all species of aquatic plants discussed in this manual.

\section{Tanks}

Tanks are excellent vessels for growing aquatic plants. The advantages of tank culture include accessibility, water quality management, and separation of species. Many sizes and shapes of fiberglass and plastic tanks are available commercially. While these are generally manufactured for the aquaculture of fish and invertebrates, some models are well suited for culturing aquatic plants. When selecting tanks, ensure that tank depth is suitable for the species of plants to be cultivated. Another consideration is tank dimension. Easy access is critical to good plant cultivation. A tank width of about $1 \mathrm{~m}$ may be the maximum for easy access to plants. For many species of submersed and floating-leaved plants, tanks in the range of 0.75 to $1.0 \mathrm{~m}$ deep by $1.0 \mathrm{~m}$ wide by appropriate length (5 or more $\mathrm{m}$ ) are recommended. For ease of operation, tanks should be accessible from both sides. Shallow tanks $(25 \mathrm{~cm})$ are suitable for emergent species.

Construction of custom tanks may be desirable and cost-effective on many projects. For long-term cultivation, concrete vats can be made to size for specific plant types. Permanent plumbing, including filling and drainage piping, can be included in such structures. Less expensive, custom tanks can be constructed from available building materials (lumber or concrete blocks) and pond liner material.

\section{Shelters}

Greenhouses, hothouses, and cold frames can be incorporated into tank designs to extend the growing season for many plant species. Some degree of protection may be needed for plants in northern areas, where water in tanks can freeze solid. An advantage to moderating temperatures (and possibly photoperiod) is early season production of plants-i.e., mature transplants can be produced, ready for transplanting as soon as project conditions allow. Without temperature and/or light control, most native plants will remain dormant until temperatures rise in the spring, reducing the transplant window during a particular season.

Excessive solar heating can be a serious problem, especially in aboveground tanks. Hot, sunny days may cause excessively high temperatures within tank cultures, and plants may suffer high mortality. Because excessive light can also damage submersed aquatic plants, covering tanks with a light grade (30- to 50 -percent reduction of sunlight) shade cloth is recommended. This will reduce both light intensity and temperature.

Shading for floating-leaved or emergent species is not generally necessary. 


\section{In-Lake Production}

In-lake cultivation may be preferred for many projects, especially when available culture facilities are located some distance away from the project. Transportation of mature transplants over long distances can be logistically difficult and stressful to the plants. In these cases, construction of plant production nurseries within the project water body is recommended.

A simple design that these authors use illustrates the basic components of an in-lake nursery (Figure 2). A large but movable container (such as a kiddie pool) for holding and stabilizing the pots and a protective fence to prevent grazing (and other disturbances) are required. Pots are filled with lake sediments and planted with propagules (from local or other sources); the plants are allowed to grow within the protection of the fencing. When plants are mature, they can be moved to designated sites and transplanted. The emptied pots can then be refilled with sediment substrate, and a subsequent crop can be started to ensure a continued supply of mature transplants (or other propagules) throughout the growing season.

\section{Planting the Containers}

The general procedure for making potted aquatic plants (mature transplants) is as follows:

a. Fill pot to about one-fourth full (above the drainage perforations) with potting medium.

b. Add an appropriate dose of fertilizer.

c. Fill remaining three-fourths of the pot with medium.

d. Place pots in growing vessel (pond, tank, etc.)

$e$. Slowly fill growing vessel to 10 or $15 \mathrm{~cm}$ above the pot with clean water to allow the potting medium to become saturated. Apply pressure to consolidate the substrate, expressing any trapped air or water and eliminating voids. Add additional medium if necessary.

f. Allow filled pots to "cure" for 1 to several weeks - particularly if using a nonaquatic substrate. An initial nutrient pulse is generally observed as some nutrients and organics are released into the water. This is evidenced by brown staining of the water by humic materials or by the presence of an organic film on the water surface. Flush the water and refill several times if necessary.

g. Make an indentation in the center of the potting medium. 


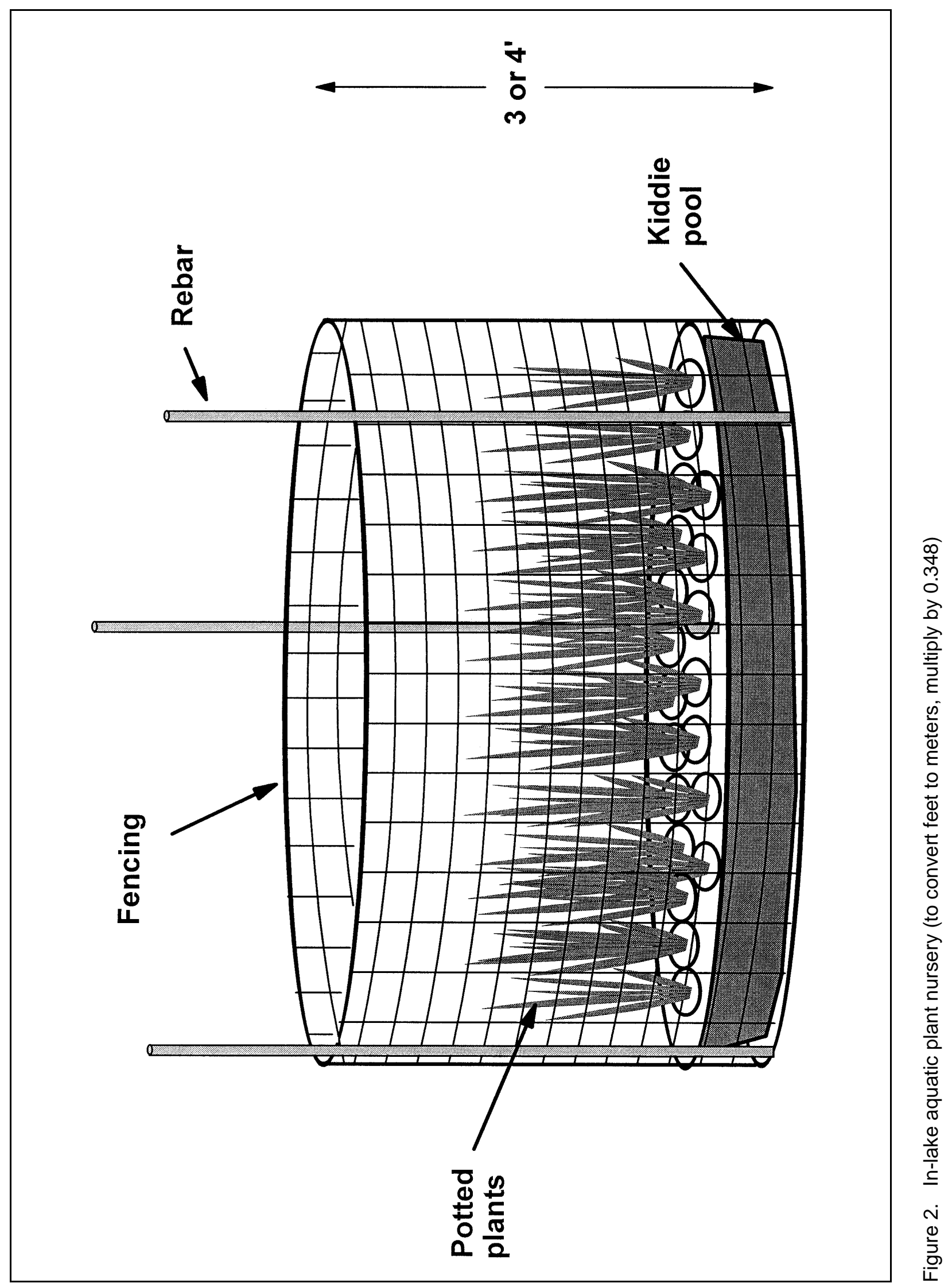


$h$. Plant the propagule and "backfill" to ensure that the plant is anchored.

$i$. Fill the growing vessel to the desired cultivation depth with clean water.

\section{Propagule Types}

Many commercial suppliers sell aquatic plant propagules. These authors generally do not recommend using these propagules for establishing plant colonies in lakes and reservoirs, but they are often adequate as starter materials for plant propagule production in tanks or ponds. Availability is often seasonal, and locality concerns should be carefully weighed. If local or regional populations of a particular species are known, harvesting from these populations to obtain starter propagules is recommended.

Stem fragments, daughter plants, root crowns, tubers or winterbuds, and even seeds (usually dependent upon species) may be used as starter materials for aquatic plant cultures. Planting more pots than needed for a project is suggested if other projects are planned in the future. After a culture of a particular species is established, it can be used as a source for the next generation of cultivation. This prevents excessive damage that might be inflicted on donor populations if repetitive annual collections were required.

\section{Stem fragmenters}

Many aquatic plant species spread vegetatively from stem fragments. These species have apical meristems at the terminal ends of the shoots. Select stem tips and cut to a length of 15 to $20 \mathrm{~cm}$. When selecting material, remember that the greater the density of leaves along the stem, the better, as most nodes can produce roots as well as leaves and branches. Plant the apical cutting about 8 to $10 \mathrm{~cm}$ deep in the potting medium. For faster development, several cuttings could be planted per pot. Established plants readily regenerate new meristematic tissues after cutting, so once the culture is actively growing, additional cuttings can be taken to plant additional pots.

\section{Rosette plants}

Some aquatic plant species grow in a rosette form, reproducing by producing daughter plants along stolons. To propagate these species, small plants should be clipped from the parent and planted directly into pots. These plants have a basal meristem, and care must be taken not to cover this growing tip when planting. A relatively dense, firm substrate is important for these species because they are buoyant and, without sufficient anchoring, are easily dislodged from the potting medium. A layer of coarse sand or fine gravel can be placed over the substrate to help anchor the plants. Once pots are established, 
additional plantings can be made by removing daughter plants as they appear on stolons or by dividing potted plants.

\section{Dormant perennating plants}

Many aquatic plants perennate by producing tubers or winterbuds that survive winter or dry periods in a dormant state. The use of tubers or winterbuds is an excellent way to start a culture. Dormant propagules can be collected, held in a dormant state by refrigeration (for up to 6 weeks), and then planted when desired. Tubers are buoyant and should be planted about $5 \mathrm{~cm}$ deep and covered completely with potting medium and/or coarse sand. Extra pots (or larger containers) can be prepared and the plants allowed to grow and complete their annual life cycle to produce tubers that can be harvested and used either for restoration projects or to produce subsequent crops.

\section{Annual species}

Almost all of the aquatic plant species that might be used for restoration projects produce viable seed. However, the ease of propagation of most aquatic plants by other means and rather limited knowledge of seed storage and germination requirements limit the usefulness of seed as a starting material for producing plant propagules. Seed- or spore-laden sediments (obtained from drained pond cultures) have been used to start plants of several annual species such as southern naiad (Najas guadalupensis), slender pondweed (Potamogeton pusillus), horned pondweed (Zannichellia palustris), or muskgrass (Chara spp.). Seeds are also the propagule of choice for American lotus (Nelumbo lutea).

Appendix A lists the types of propagules recommended as starter materials for producing transplants of selected aquatic plant species.

\section{Culture Maintenance}

\section{Weeds}

As with any culture or crop, nuisance weeds or pests may cause problems. Pond sediments often contain seeds and spores of aquatic species that might interfere with production of desired species. Although expensive and labor intensive, sediments can be heat sterilized to avoid or reduce this problem. Hand weeding will be required to remove unwanted plants, but this also is timeconsuming and labor intensive.

Inadequate separation of plant species in mixed pond or tank cultures can also lead to cross contamination and "weed" infestations, especially where production of single-species transplants is critical. Growing monocultures in 
separate tanks will usually prevent cross contamination. If contamination does occur, rigorous hand weeding will be necessary to correct the problem.

\section{Algae}

Excessive algal growth is always a concern with cultures of submersed aquatic plants. High concentrations of nutrients (especially phosphorus and nitrogen) in the water column will generally support excessive algal growth. Algae, whether growing in the water, on the water surface, or on the plants themselves, cause problems by reducing the growth of desired plants. Algae compete with macrophytes for light, nutrients, and inorganic carbon, and, because they are capable of rapid growth, they can quickly grow to problem levels. Once algae become well established in a culture, they are difficult to control; so prevention is prudent. As mentioned earlier, using low-nutrient water and avoiding excess fertilizer will usually prevent algal problems. Reduction of existing algal blooms will require exchanging the water with low-nutrient water and either hand removal of filamentous growths or filtering the water to remove phytoplankton ("green" water).

\section{Grazing pests}

Herbivore damage may become a problem in some situations. Pond and inlake plant cultures must be protected from turtles, carp, waterfowl, muskrats, and some invertebrates. Protective devices are discussed in the following chapter. Aphids and caterpillars can reach nuisance proportions in tank cultures and may require chemical control. 


\section{Implementation}

\section{Site Selection}

Sites should be selected based upon several criteria. Choose well-protected (from winds and wave action), shallow ( $<2-\mathrm{m}$ depths) coves-preferably with gradual slopes-for establishment of aquatic plants. A fine-textured substrate is preferred and generally indicates a favorable, low-energy environment. Other than as an indicator of physical conditions, sediment texture does not seem to be critical to successful short-term establishment, and similar results have occurred on sandy to muddy substrates. The major consideration is that plant roots must be able to penetrate the sediment to a depth of at least $15 \mathrm{~cm}$ in order to anchor the plant.

Avoid developed areas and areas favored by bank fishermen, swimmers, and users of recreational water craft. Wooded shorelines can be a problem due to excessive shading, which greatly reduces the light available to submersed aquatic plants. Areas with signs of heavy animal activity-particularly hogs, cattle, or beaver-should also be avoided.

\section{Planting Depth}

The two greatest abiotic influences on aquatic establishment are water-level fluctuations and high turbidity. Because submersed aquatic plants require light to establish, plant in shallow depths - particularly if the water is turbid. Water levels of most reservoirs are influenced by both natural (seasonal or climatic) events and operations (storage or release of floodwaters or water supplies, power generation, etc.), both of which are generally beyond one's control. For planning purposes, historic water-level fluctuations are reviewed to estimate expected levels during early establishment. Based on expected water levels and knowledge of the biology of the plant species, an appropriate depth or depth range is assigned for each species. In general, submersed plants will establish best at depths of 0.5 to $1.0 \mathrm{~m}$, floating-leaved plants from 25 to $75 \mathrm{~cm}$, and emergent plants from 0 to $25 \mathrm{~cm}$. 
Avoid areas of high sediment resuspension by selecting wind- and waveprotected coves. These are generally the clearest shallow waters available. The use of mature transplants, with well-developed shoots and/or leaves, is mandatory in turbid waters. Introducing a $75-\mathrm{cm}$-tall plant into 50 to $75 \mathrm{~cm}$ of water ensures that at least some photosynthetic surfaces will receive adequate light.

\section{Species Selection}

Plant species should be selected based upon several criteria. Overall, using only native plant species is suggested, as these tend not to reach weedy proportions, reducing the need for future intensive management. Establishing as great a species diversity as possible is also suggested. This will ensure long-term establishment of at least some species (e.g., drought-tolerant species will survive long drawdowns, while others may not). Diverse communities of native plants will provide the greatest water quality and habitat benefits over the long term.

Plants should be selected based on specific lake habitats or anticipated environmental conditions. For instance, in a lake known to follow a pattern of water-elevation change, concentrating on drought-tolerant species may be best. However, because predicting environmental changes in a reservoir is difficult, conducting a test planting of as many species as possible is strongly recommended to ensure an adequate evaluation.

Several species that have demonstrated potential for lake restoration are provided, along with information about their culture and planting, in Appendix A.

\section{Timing}

Timing and site selection can be as critical as species selection. Planting should occur prior to or during periods of active growth to ensure establishment during that growing season. Unlike seeds or less robust propagules, mature transplants can be planted over a relatively long period of time. Depending on location, this may range from midspring to late summer. In reservoirs that experience spring floods, planting should be delayed until water levels drop to their normal summer levels. In general, plants should be planted as early as practicable. Establishment of a viable population from mature transplants is possible in late summer, but late planting reduces the length of growing season remaining and decreases the likelihood of success.

\section{Herbivore Protection}

Establishment of new colonies of aquatic plants in unvegetated reservoirs requires protection from herbivores (Smart et al. 1996; Doyle et al. 1997). 
Several types of protective exclosures have been used, depending on the expected level of herbivory. Site visits, discussions with lake and fisheries managers, and trapping can provide preliminary estimates of the densities of herbivorous species that may be encountered.

Several of the following small-scale exclosures can provide near-complete protection from herbivory if constructed of appropriate materials and properly deployed. However, because these exclosures protect only a single, relatively small clump of plants, they may be most useful in situations where herbivory is low to moderate. Larger herbivore exclosures offer protection from omnivores such as carp and other rough fish. These are used in situations where rough fish population densities are expected to be high or in reservoirs previously stocked with grass carp.

\section{Individual plant protection}

Cylinders constructed of wire-mesh fencing can provide economical and reliable protection for individual transplants. Cylinders 60 to $90 \mathrm{~cm}$ in diameter by 91 or $122 \mathrm{~cm} \mathrm{(} 3$ or $4 \mathrm{ft}$ ) high, constructed from 2 - by 4 -in. mesh welded-wire fencing and anchored with 152- or 183-cm (5- or 6-ft) lengths of three-eightsinch rebar (Figure 3) have been successfully used. The rebar can be "weaved" through the fence mesh material and then driven into the bottom sediment to secure and anchor the cylinder. Alternatively, the two pieces of rebar can be driven into the bottom (on the inside of the cylinder) and the cylinder secured to them with black (ultraviolet radiation resistant) plastic cable ties. For submersed plants placed in depths where the water level will be near the top of (or may sometimes overtop) the exclosure, opposite sides can be cinched together with wire ties or cable ties (between the two pieces of rebar) to close the top and prevent entry of turtles and other herbivores.

These individual plant exclosures are designed to protect single transplants from larger omnivores such as adult turtles, carp, nutria, etc. If protection from juvenile turtles and/or crayfish is needed, exclosures can be made from finer mesh material. Alternatively, a "sleeve" of a finer mesh material (such as orange plastic construction fencing) can be placed over the wire mesh cylinder (Figure 3). The advantage of this approach is that the sleeve can likely be removed and reused after initial establishment of the transplant.

\section{Multiple plant protection}

Larger exclosures protect multiple plants. These can be constructed of wiremesh fencing or orange plastic construction fencing. Square cages 150 or 180 $\mathrm{cm}$ (5 or $6 \mathrm{ft}$ ) on a side, constructed of 122- or 183-cm (4- or 6-ft) high, 1-in. diamond mesh (Tenax "Sentry Secura") orange plastic construction fencing, rebar, and PVC piping have been successfully used (Figure 4 and Smart et al. 1996). These exclosures can be assembled on shore, rolled up, and transported to the planting locations when ready. At the site, a four-person crew sets the 


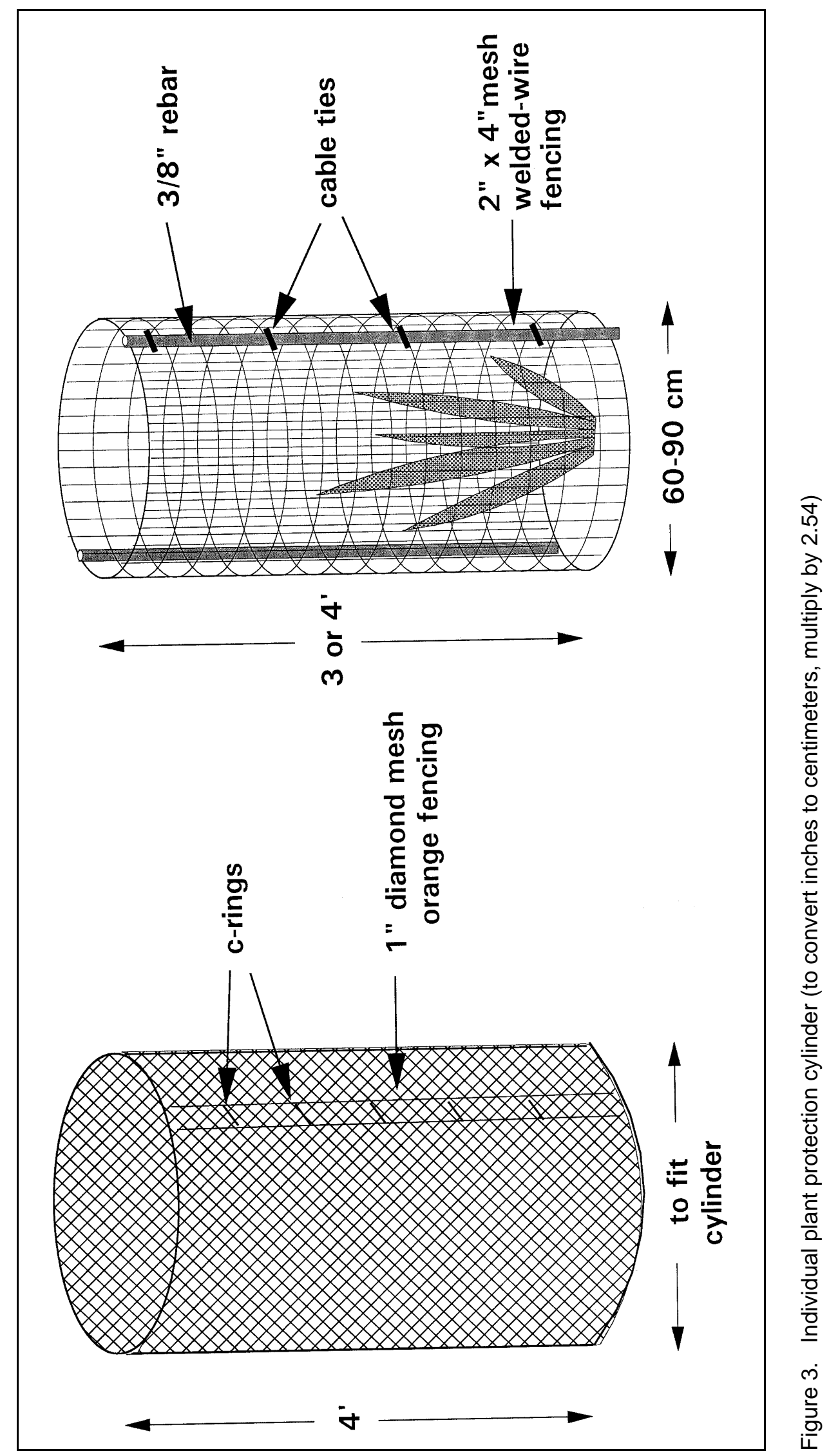

Chapter 3 Implementation 


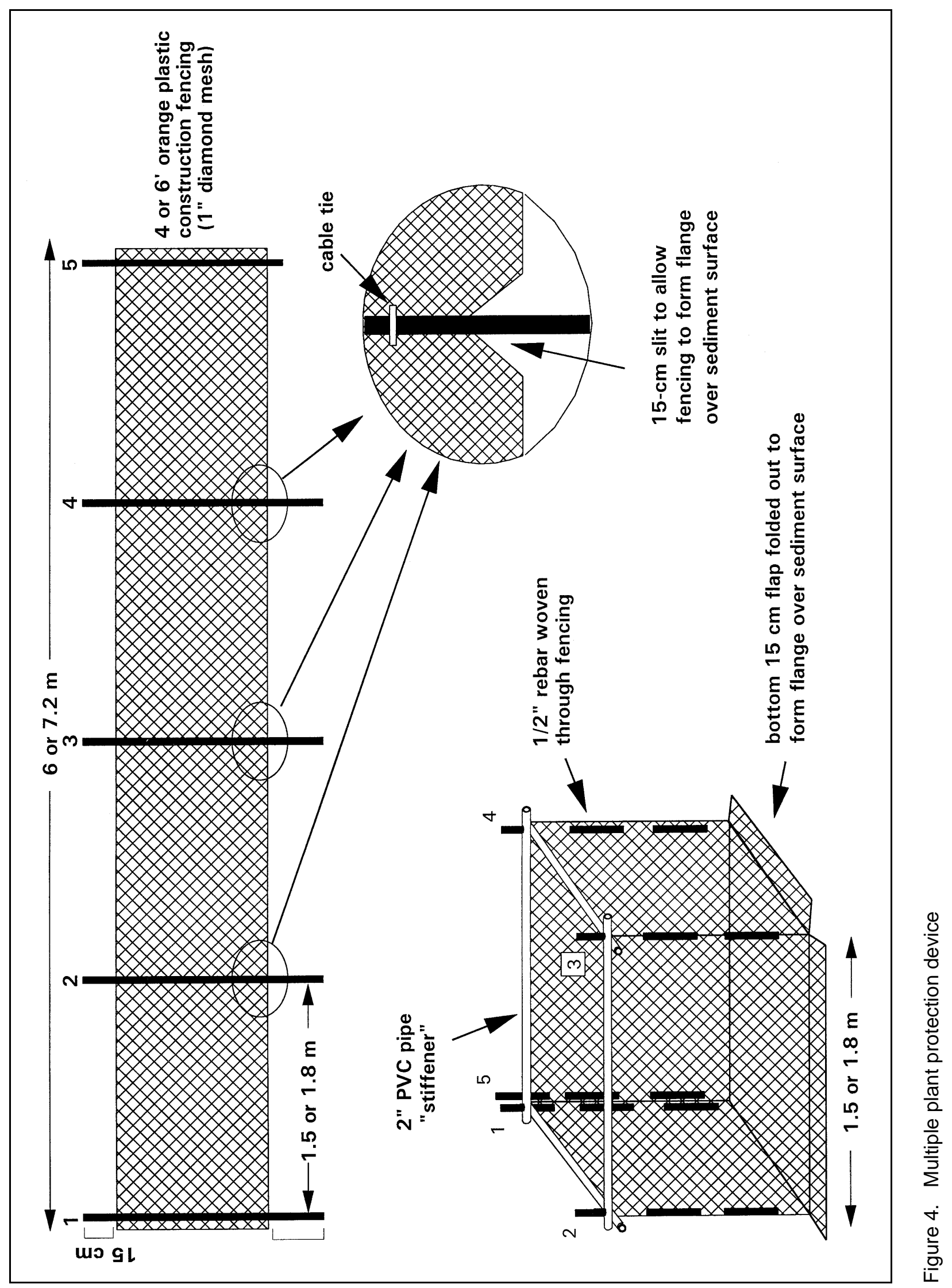


corners, ensures that the bottom flap is folded out to form a flange, and anchors Posts 1 through 4 . The shorter fifth piece of rebar is used to secure the opening after planting. Precut and drilled lengths of 2-in. PVC are placed over the rebar to stiffen the exclosure and prevent turtles from climbing over the top. These can be secured with black plastic cable ties, and, if necessary, the fence fabric can also be secured to the PVC with similar ties.

These multiple plant exclosures are usually planted with four or five transplants and may be suitable for harsh environments where survival of an individual transplant may be in doubt. The larger area of the resultant population may also sustain a higher grazing pressure than would an individual plant unit. The smaller mesh size of the construction fencing also provides more complete protection from most herbivores and omnivores. An additional advantage is that the material is highly visible, making the exclosures easy to find for monitoring and evaluation and also easy for boaters to avoid. Drawbacks include greater expense, difficulty of construction, and less durability in comparison with wire-mesh exclosure designs.

\section{Fenced plots}

Fenced plots protect even larger planted areas-generally $3 \mathrm{~m}$ or greater on a side. Square or rectangular fenced areas constructed from T-posts and 122-, 152-, or 183-cm (4-, 5-, or 6-ft) high, 2- by 4-in. mesh welded-wire fencing have been used (Figure 5). T-posts can be placed on 2.5- to 3.5-m centers and the fence attached with wire fence ties. The interface between the fence and the bottom sediment is critical, and a outward flap at the bottom of the fence may help to prevent entry of turtles, carp, and other large grazers.

Fenced plots can be planted at a density of 0.4 to 0.8 plants/square meter. These larger exclosures may be most suitable for reservoirs that are expected to have high numbers of carp and/or other grazers.

\section{Shoreline fences}

A shoreline fence is a three-sided modification of the above fenced plot design. These are irregular in size, extending from the shoreline out to, for example, the 1-m contour and then along that contour parallel to the shore. These are also constructed of 122-, 153-, or 183-cm (4- or 6-ft) high, 2- by 4-in. mesh welded-wire fencing attached to T-posts.

Because shoreline fences do not exclude herbivores that can move over land (turtles, nutria, muskrat, beavers), the plants may require a double layer of herbivore protection (individual plant exclosure plus the shoreline fence). The area enclosed by the shoreline fences should be planted at densities similar to those for fenced plots. 


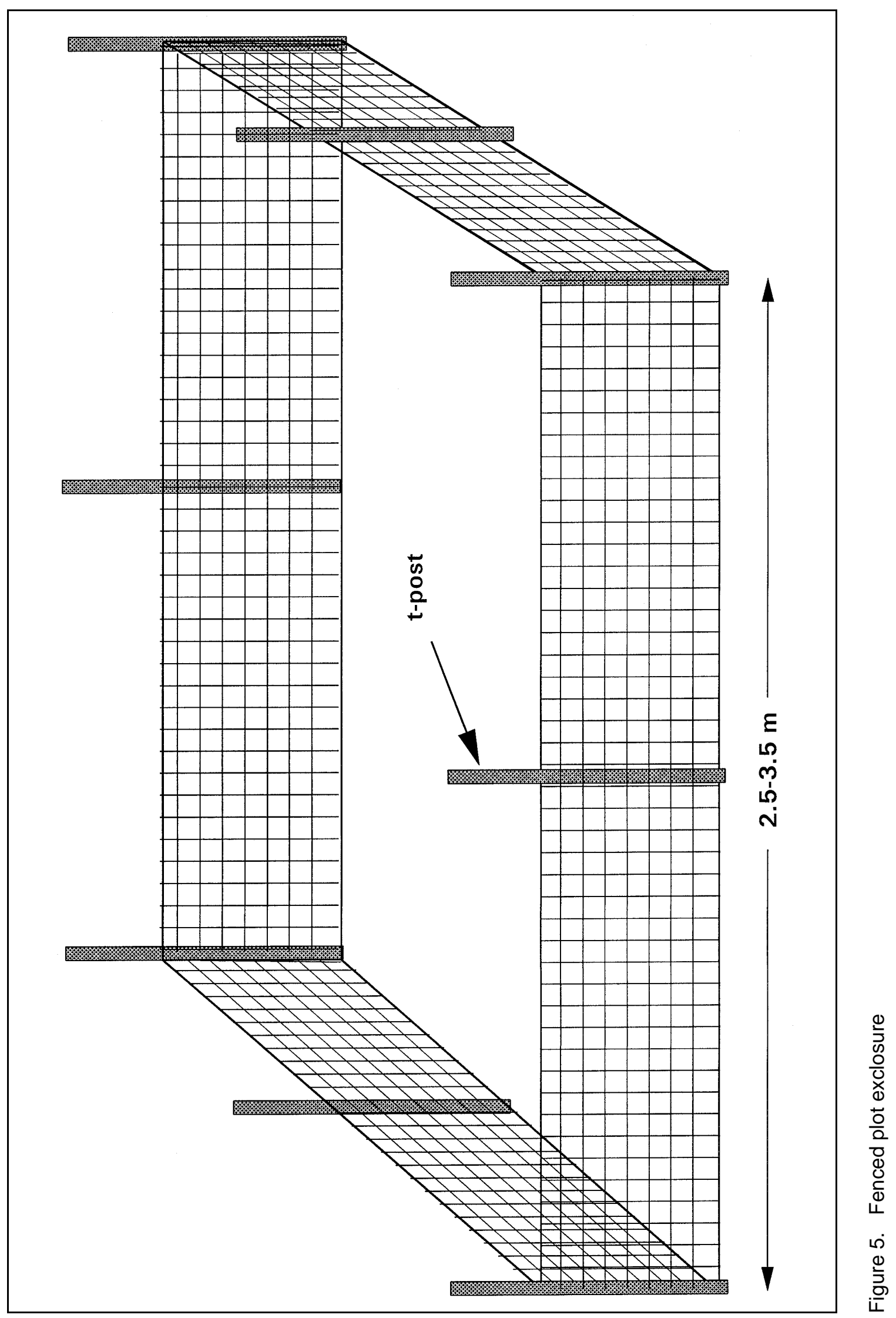




\section{Fenced coves}

Cove areas can be isolated from the main body of the reservoir with fences constructed of 2- by 4-in. mesh welded-wire fencing and T-posts. Construction is similar to that for fenced plots except that the fence is placed across the mouth of a small cove (Figure 6). Water depth at the deepest portion of the cove opening should be considered when selecting cove sites. If maximum depth exceeds $1.5 \mathrm{~m}$, the design may require alteration to increase strength and rigidity. For strength and appearance, the top of the fence should be level. Because depth will vary across the cove opening, different fence heights can be used to ensure that the fence contacts the bottom.

Like shoreline fences, fenced coves do not exclude herbivores that can move over land, and plants may require a double layer of herbivore protection (individual plant exclosure plus the cove fence). Avoid coves with large, inflowing creeks because the fence will trap logs and other debris and may be subject to damage or undercutting during high-flow events.

\section{Monitoring and Redirecting}

A diagrammatic representation of the founder colony approach is given in Figure 1. A suitable cove (one with an expanse of shallow water, suitable sediments, and a relatively protected location) is identified. Phase 1 involves planting and monitoring (over a full growing season) of test plants of a variety of species within small protective exclosures. Assuming suitable sediments, water quality, and water levels, these plants will establish and expand beyond their protective cages, depending on the level of herbivory. During Phase 1, the level of herbivory and, if possible, the sizes and types of herbivores should be noted. Monitoring during Phase 1 is important because the response of the plants will dictate the best course of action to take during subsequent growing seasons.

During the second growing season, those species performing best during Phase 1 should receive additional plantings. However, in many unvegetated reservoirs, expansion of the plantings will require provision of a larger scale protected environment such as a fenced cove. Phase 2 may involve construction of a fence across the cove mouth to exclude carp and other rough fish in combination with additional plantings of selected or preferred species. Phase 2 should result in the successful establishment of founder colonies of several species.

During Phase 3, the colonies expand to fill the niche within the fenced cove and begin to spread into unprotected areas by vegetative and/or sexual modes of reproduction. Monitoring should not be discontinued at this stage, as large-scale disturbances can have serious consequences on newly established plant communities. Additional species may also be desirable to ensure maximum diversity, stability, and resilience of the aquatic plant community. 


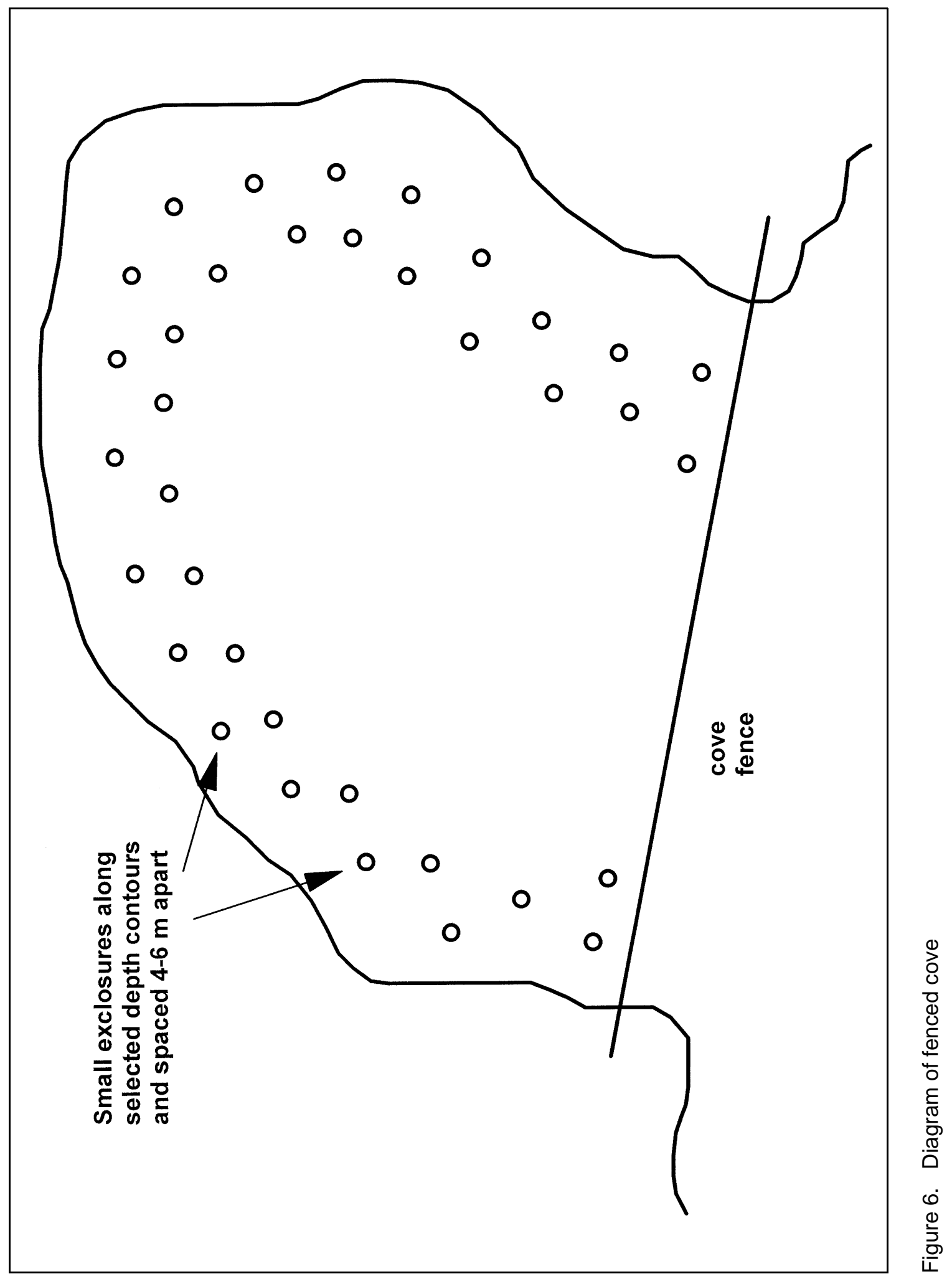




\section{References}

Barko, J. W., and Smart, R. M. (1983). "Effects of organic matter additions to sediment on the growth of aquatic plants," J. Ecol.71, 161-175.

. (1986). "Sediment-related mechanisms of growth limitation in submersed macrophytes," Ecology 67, 1328-1340.

Dibble, E. D., Killgore, K. J., and Harrel, S. L. (1996). "Assessment of fishplant interactions." Multidimensional approaches to reservoir fisheries management. L. E. Miranda and D. R. DeVries, ed., Amer. Fish. Soc. Symp. $16,347-356$.

Dick, G. O., Getsinger, K. D., and Smart, R. M. (1997). “Outdoor mesocosm systems for evaluating aquatic herbicides: Operating manual," Technical Report A-97-3, U.S. Army Engineer Waterways Experiment Station, Vicksburg, MS.

Dick, G. O., Smart, R. M., and Keiser, E. D. (1995). "Populations of turtles and their potential impacts on aquatic plants in Guntersville Reservoir, Alabama," Joint Agency Guntersville Project Aquatic Plant Management, Tennesee Valley Authority Report.

Doyle, R. D., and Smart, R. M. (1993). "Potential use of native aquatic plants for long-term control of problem aquatic plants in Guntersville Reservoir, Alabama; Report 1, Establishing native plants," Miscellaneous Paper A-95-3, U.S. Army Engineer Waterways Experiment Station, Vicksburg, MS.

. (1995). "Competitive interactions of native plants with nuisance species in Guntersville Reservoir, Alabama." Proceedings, 29th annual meeting, Aquatic Plant Control Research Program. Miscellaneous Paper A-95-3, U.S. Army Engineer Waterways Experiment Station, Vicksburg, MS, 237-242.

Doyle, R. D., Smart, R. M., Guest, C., and Bickell, K. (1997). "Establishment of native aquatic plants for fish habitat: Test plantings in two north Texas reservoirs," Lake and Reserv. Manage. 13, 259-269. 
James, W. F., and Barko, J. W. (1990). "Macrophyte influence on the zonation of sediment accretion and composition in a north-temperate reservoir," Arch Hydrobiol. 120, 129-142.

(1995). "Effects of submersed macrophytes on sediment resuspension in Marsh Lake, Minnesota." Proceedings, 29th annual meeting, Aquatic Plant Control Research Program. Miscellaneous Paper A-95-3, U.S. Army Engineer Waterways Experiment Station, Vicsksburg, MS, 168-175.

Lodge, D. M. (1991). "Herbivory on freshwater macrophytes," Aquat. Bot. 41, 195-224.

Smart, R. M., and Barko, J. W. (1984). "Culture methodology for experimental investigations involving rooted submersed aquatic plants," Miscellaneous Paper A-84-6, U.S. Army Engineer Waterways Experiment Station, Vicksburg, MS.

(1985). "Laboratory culture of submersed freshwater macrophytes on natural sediments," Aquat. Bot. 21, 251-263.

Smart, R. M., Barko, J. W., and McFarland, D. G. (1994). "Competition between Hydrilla verticillata and Vallisneria americana under different environmental conditions," Technical Report A-94-1, U.S. Army Engineer Waterways Experiment Station, Vicksburg, MS.

Smart, R. M., Dick, G. O., and Doyle, R. D. (1998). "Techniques for establishing native aquatic plants," J. Aquat. Plant Manage. (In press)

Smart, R. M., Dick, G. O., Honnell, D. R., Madsen, J. D., and Snow, J. R. (1995). "Physical and environmental characteristics of experimental ponds at the Lewisville Aquatic Ecosystem Research Facility," Technical Report A-95-2, U.S. Army Engineer Waterways Experiment Station, Vicksburg, MS.

Smart, M., and Doyle, R. (1995). "Ecological theory and the management of submersed aquatic plant communities," Aquatic Plant Control Research Program Bulletin A-95-3, U.S. Army Engineer Waterways Experiment Station, Vicksburg, MS.

Smart, R. M., Doyle, R. D., Madsen, J. M., and Dick, G. O. (1996). "Establishing native submersed aquatic plant communities for fish habitat." Multidimensional approaches to reservoir fisheries management." L. E. Miranda and D. R. DeVries, ed., Amer. Fish. Soc. Symp. 16, 347-356. 


\section{Appendix A Production and Planting Information on Selected North American Aquatic Plant Species}




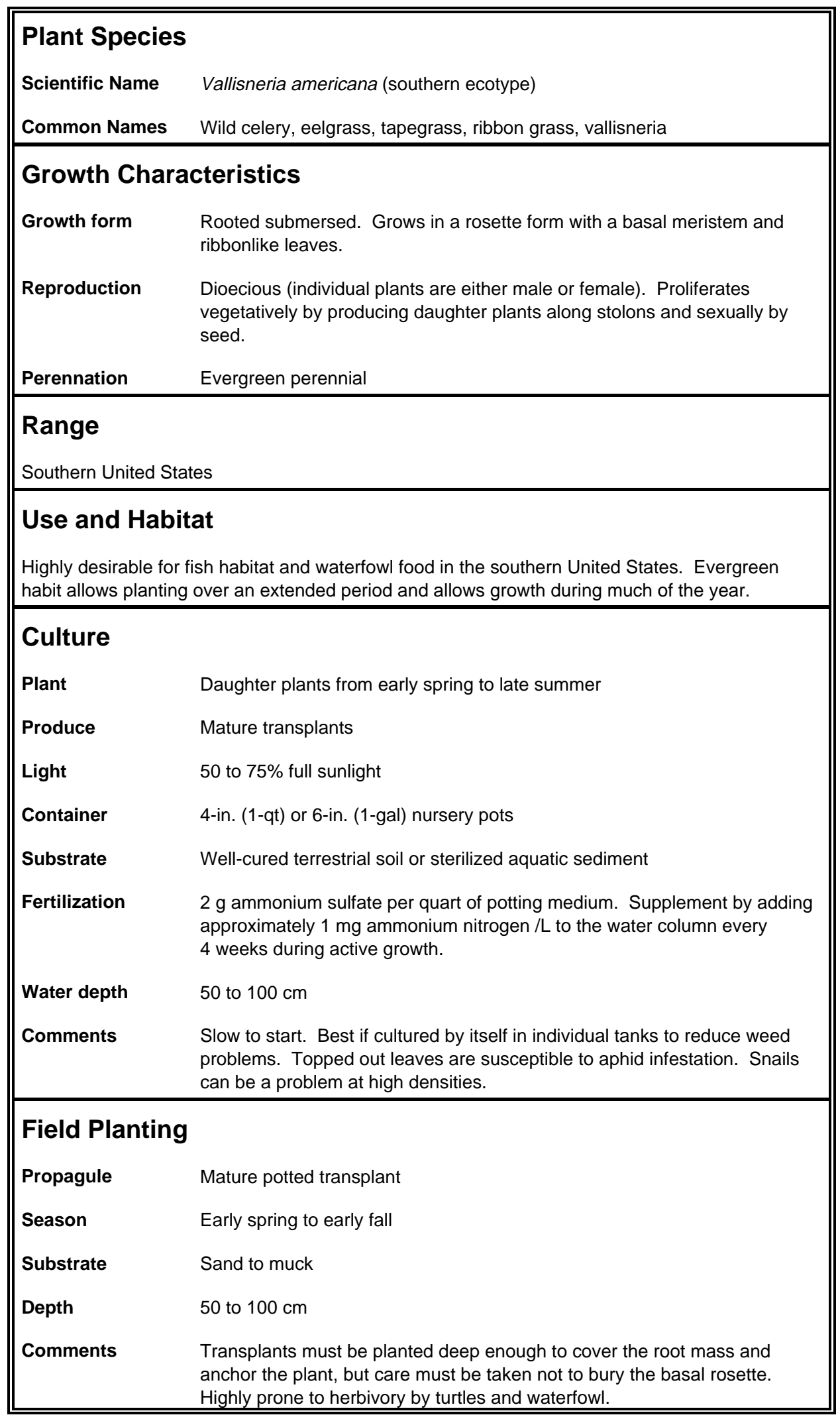




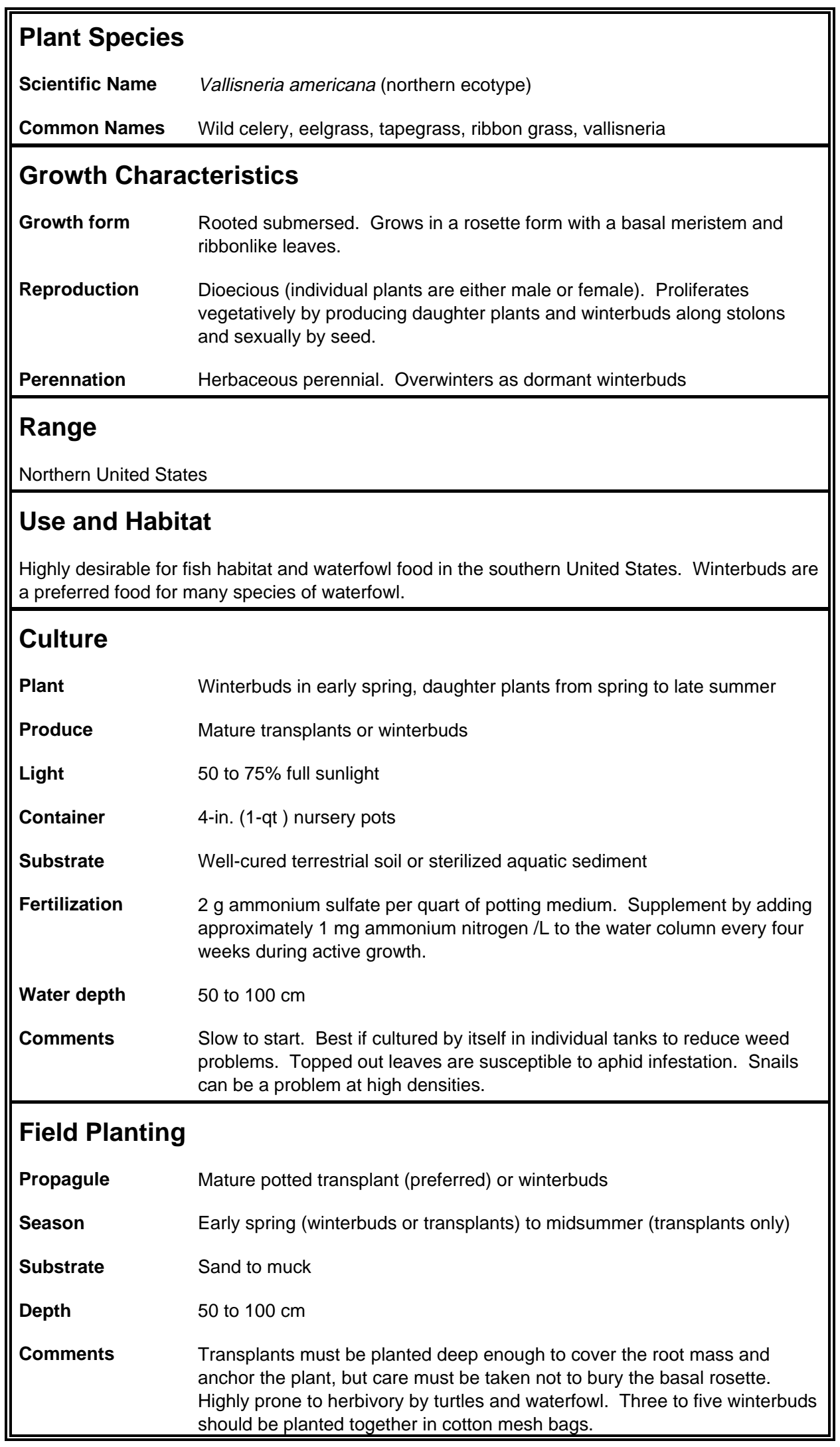




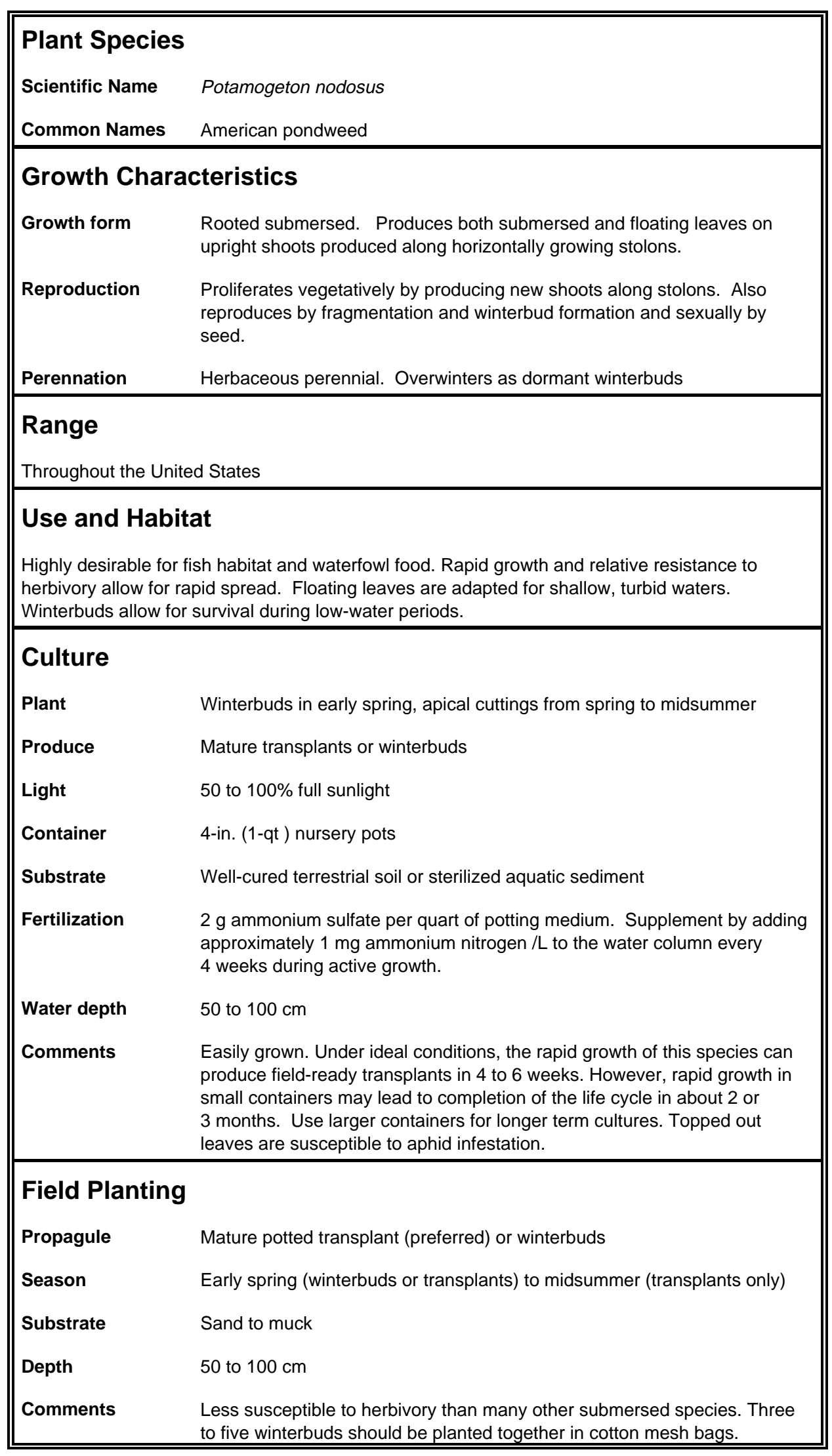




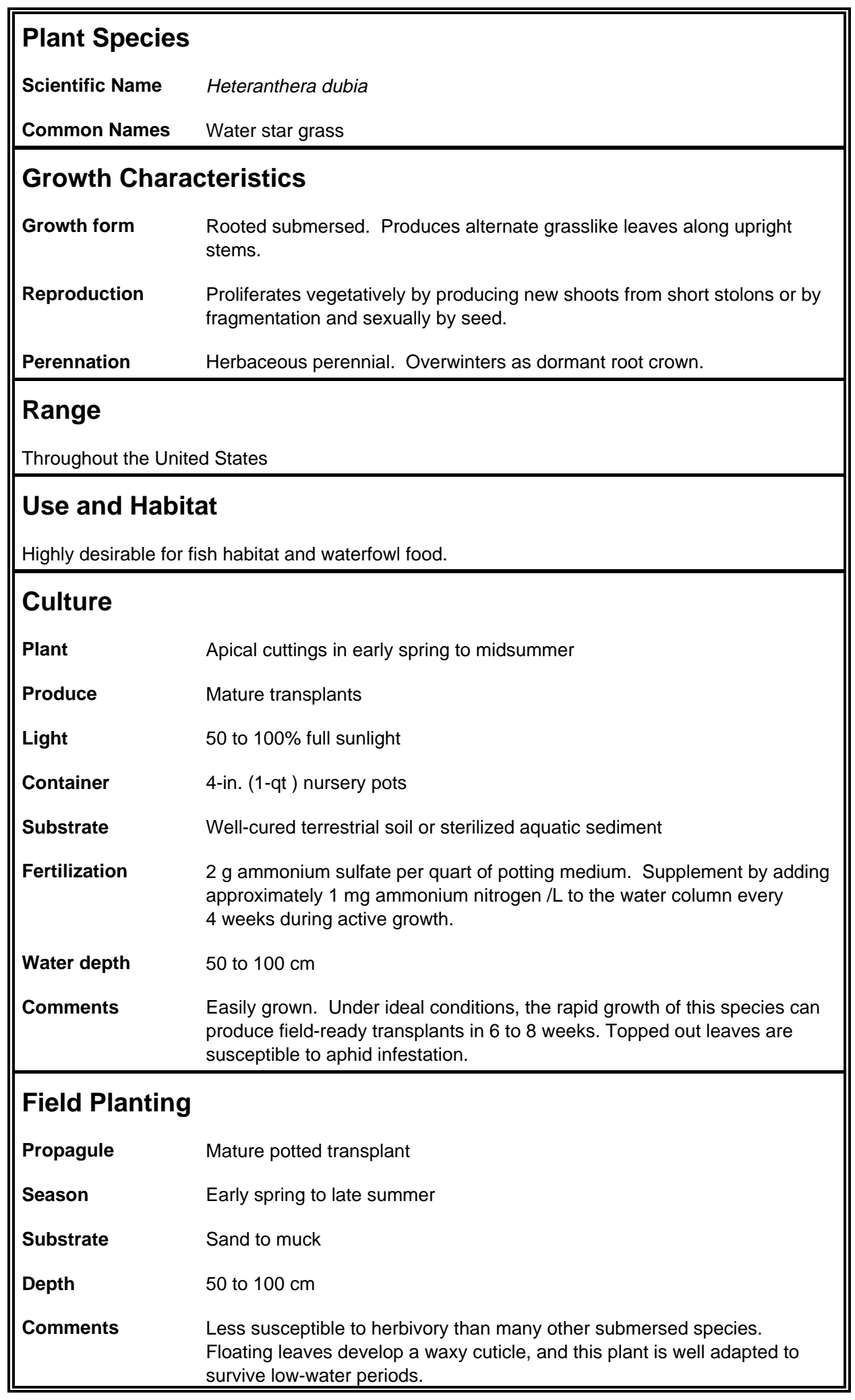




\section{REPORT DOCUMENTATION PAGE}

Public reporting burden for this collection of information is estimated to average 1 hour per response, including the time for reviewing instructions, searching existing data sources, gathering and maintaining

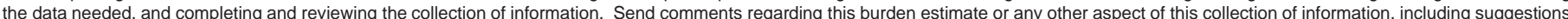

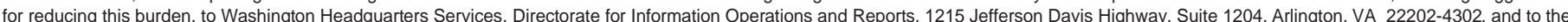
Office of Management and Budget, Paperwork Reduction Project (0704-0188), Washington, DC 20503.
1. AGENCY USE ONLY (Leave blank)
2. REPORT DATE
3. REPORT TYPE AND DATES COVERED
February 1999
Final report

\section{TITLE AND SUBTITLE}

5. FUNDING NUMBERS

Propagation and Establishment of Aquatic Plants: A Handbook for Ecosystem

Restoration Projects

6. AUTHOR(S)

R. Michael Smart, Gary O. Dick

\section{PERFORMING ORGANIZATION NAME(S) AND ADDRESS(ES)}

U.S. Army Engineer Waterways Experiment Station

3909 Halls Ferry Road

Vicksburg, MS 39180-6199

8. PERFORMING ORGANIZATION REPORT NUMBER

Technical Report A-99-4

9. SPONSORING/MONITORING AGENCY NAME(S) AND ADDRESS(ES)

U.S. Army Corps of Engineers

Washington, DC 20314-1000

\section{SUPPLEMENTARY NOTES}

Available from National Technical Information Service, 5285 Port Royal Road, Springfield, VA 22161.

\section{2a. DISTRIBUTION/AVAILABILITY STATEMENT}

12b. DISTRIBUTION CODE

Approved for public release; distribution is unlimited.

\section{ABSTRACT (Maximum 200 words)}

Unlike natural lakes, reservoirs generally do not have well-developed aquatic plant communities. As man-made ecological systems, reservoirs are relatively young and often lack aquatic plant propagules of appropriate native plant species. These man-made systems are also operated to achieve specific project objectives such as flood control, navigation, etc. As a result of these reservoir operations, water levels often fluctuate dramatically, making natural establishment of aquatic plants from seeds difficult or impossible. Reservoirs are also frequently populated by large numbers of opportunistic omnivores such as common carp. Grazing by these omnivores and aquatic herbivores may be too intense to allow natural establishment, particularly in light of the low numbers of propagules and relatively harsh environmental conditions offered by many reservoirs.

In order to establish a diverse native plant community, robust propagules of desirable aquatic plant species must be introduced into selected, favorable environments and be provided with protection from grazing during early establishment. This handbook provides general information on production of aquatic plant propagules and methods of planting that should facilitate the development of diverse native plant communities. An appendix provides specific information on propagation and planting of selected native aquatic plant species.

\section{SUBJECT TERMS}

Aquatic plant establishment Aquatic plant management Aquatic plant propagation
Aquatic plant restoration

Herbivory

Native aquatic plants
15. NUMBER OF PAGES

37

16. PRICE CODE

\begin{tabular}{|l|c|c|}
\hline $\begin{array}{l}\text { 17. SECURITY CLASSIFICATION } \\
\text { OF REPORT } \\
\text { UNCLASSIFIED }\end{array}$ & $\begin{array}{c}\text { 18. SECURITY CLASSIFICATION } \\
\text { OF THIS PAGE } \\
\text { UNCLASSIFIED }\end{array}$ & $\begin{array}{c}\text { 19. SECURITY CLASSIFICATION } \\
\text { OF ABSTRACT }\end{array}$ \\
\hline \hline
\end{tabular}

NSN 7540-01-280-5500
Standard Form 298 (Rev. 2-89) Prescribed by ANSI Std. Z39-18 298-102 


\section{References}

Barko, J. W., and Smart, R. M. (1983). "Effects of organic matter additions to sediment on the growth of aquatic plants," J. Ecol.71, 161-175.

. (1986). "Sediment-related mechanisms of growth limitation in submersed macrophytes," Ecology 67, 1328-1340.

Dibble, E. D., Killgore, K. J., and Harrel, S. L. (1996). "Assessment of fishplant interactions." Multidimensional approaches to reservoir fisheries management. L. E. Miranda and D. R. DeVries, ed., Amer. Fish. Soc. Symp. $16,347-356$.

Dick, G. O., Getsinger, K. D., and Smart, R. M. (1997). “Outdoor mesocosm systems for evaluating aquatic herbicides: Operating manual," Technical Report A-97-3, U.S. Army Engineer Waterways Experiment Station, Vicksburg, MS.

Dick, G. O., Smart, R. M., and Keiser, E. D. (1995). "Populations of turtles and their potential impacts on aquatic plants in Guntersville Reservoir, Alabama," Joint Agency Guntersville Project Aquatic Plant Management, Tennesee Valley Authority Report.

Doyle, R. D., and Smart, R. M. (1993). "Potential use of native aquatic plants for long-term control of problem aquatic plants in Guntersville Reservoir, Alabama; Report 1, Establishing native plants," Miscellaneous Paper A-95-3, U.S. Army Engineer Waterways Experiment Station, Vicksburg, MS.

. (1995). "Competitive interactions of native plants with nuisance species in Guntersville Reservoir, Alabama." Proceedings, 29th annual meeting, Aquatic Plant Control Research Program. Miscellaneous Paper A-95-3, U.S. Army Engineer Waterways Experiment Station, Vicksburg, MS, 237-242.

Doyle, R. D., Smart, R. M., Guest, C., and Bickell, K. (1997). "Establishment of native aquatic plants for fish habitat: Test plantings in two north Texas reservoirs," Lake and Reserv. Manage. 13, 259-269. 
James, W. F., and Barko, J. W. (1990). "Macrophyte influence on the zonation of sediment accretion and composition in a north-temperate reservoir," Arch Hydrobiol. 120, 129-142.

(1995). "Effects of submersed macrophytes on sediment resuspension in Marsh Lake, Minnesota." Proceedings, 29th annual meeting, Aquatic Plant Control Research Program. Miscellaneous Paper A-95-3, U.S. Army Engineer Waterways Experiment Station, Vicsksburg, MS, 168-175.

Lodge, D. M. (1991). "Herbivory on freshwater macrophytes," Aquat. Bot. 41, 195-224.

Smart, R. M., and Barko, J. W. (1984). "Culture methodology for experimental investigations involving rooted submersed aquatic plants," Miscellaneous Paper A-84-6, U.S. Army Engineer Waterways Experiment Station, Vicksburg, MS.

(1985). "Laboratory culture of submersed freshwater macrophytes on natural sediments," Aquat. Bot. 21, 251-263.

Smart, R. M., Barko, J. W., and McFarland, D. G. (1994). "Competition between Hydrilla verticillata and Vallisneria americana under different environmental conditions," Technical Report A-94-1, U.S. Army Engineer Waterways Experiment Station, Vicksburg, MS.

Smart, R. M., Dick, G. O., and Doyle, R. D. (1998). "Techniques for establishing native aquatic plants," J. Aquat. Plant Manage. (In press)

Smart, R. M., Dick, G. O., Honnell, D. R., Madsen, J. D., and Snow, J. R. (1995). "Physical and environmental characteristics of experimental ponds at the Lewisville Aquatic Ecosystem Research Facility," Technical Report A-95-2, U.S. Army Engineer Waterways Experiment Station, Vicksburg, MS.

Smart, M., and Doyle, R. (1995). "Ecological theory and the management of submersed aquatic plant communities," Aquatic Plant Control Research Program Bulletin A-95-3, U.S. Army Engineer Waterways Experiment Station, Vicksburg, MS.

Smart, R. M., Doyle, R. D., Madsen, J. M., and Dick, G. O. (1996). "Establishing native submersed aquatic plant communities for fish habitat." Multidimensional approaches to reservoir fisheries management." L. E. Miranda and D. R. DeVries, ed., Amer. Fish. Soc. Symp. 16, 347-356. 
Destroy this report when no longer needed. Do not return it to the originator. 